\title{
Global value perceptions: The legitimising functions of western representations of democracy
}

\author{
Christian Staerklé*, Juan Manuel Falomir-Pichastor†, Andrea Pereirał, Jacques Berent† \& \\ Fabrizio Butera* \\ * University of Lausanne, Switzerland \\ $\dagger$ University of Geneva, Switzerland \\ ‡ Free University of Amsterdam, Netherlands
}

\author{
Correspondence \\ Christian Staerklé, University of Lausanne, \\ Faculty of Social and Political Sciences- \\ Institute of Psychology, Geopolis Building \\ 5141, CH-1015 Lausanne, Switzerland. \\ E-mail: christian.staerkle@unil.ch
}

Received: 19 December 2014

Accepted: 23 August 2015

http://dx.doi.org/10.1002/ejsp.2159

Keywords: democracy, legitimacy, value, ideology, social representations

\begin{abstract}
This paper argues that a fundamental antagonism between democracy and nondemocracy organises lay thinking on global issues. We review key findings of a long-standing experimental research programme that examined the "Democracy-as-value" hypothesis across a variety of political and social contexts. This hypothesis contends that democracy is an ideological belief system that provides value to democratic individuals, groups, and institutions and thereby grants legitimacy to their actions. Based on procedural justice theories and social representations theory, we contend that western lay perceivers associate democracy with procedural equality and individual autonomy, whereas nondemocracy is associated with ingroup hierarchy and conformity. We discuss how idealised representations of democracy justify global power arrangements and emphasise the paradoxical justification function of democratic values through which nondemocratic forms of social regulation based on physical force are legitimised with the very democratic norms that call for peaceful resolution of conflicts.
\end{abstract}

In the case of a word like democracy, not only is there no agreed definition, but the attempt to make one is resisted from all sides. It is almost universally felt that when we call a country democratic we are praising it: consequently the defenders of every kind of regime claim that it is a democracy, and fear that they might have to stop using that word if it were tied down to any one meaning. Words of this kind are often used in a consciously dishonest way. That is, the person who uses them has his own private definition, but allows his hearer to think he means something quite different'- (George Orwell, 1946, p. 257).

For centuries, democracy has been a cornerstone of Western political thinking. Following the Enlightenment period and its vision of the sovereign individual, democracy has gradually developed into a universal principle of political modernity. Famous statements about democracy are Abraham Lincoln's Gettysburg address in 1863 where he claimed that democracy is "a government of the people, by the people, for the people", and Winston Churchill's statement in 1947 that "democracy is the worst form of government except all those other forms that have been tried from time to time". Such quotes illustrate that Western societies have long cherished the idea of democracy as a superior political system. More recently, Amartya Sen (1999) has taken the meaning of democracy beyond its political understanding and claimed that democracy is a universal value that "includes its intrinsic importance in human life, its instrumental role in generating political incentives, and its constructive function in the formation of values" (p.16).

Notwithstanding this apparent consensus concerning the moral high ground of democracy, the opening quote by George Orwell reminds us that the meaning of democracy has always been contested, and that it goes far beyond a mere description of the political organisation of a society. While many accord democracy a positive valence, what exactly is meant by it depends on the particular perspectives and circumstances in which the word is used. Democracy not only refers to a set of political procedures, but also implies the endorsement of social and moral values (Brettschneider, 2006; Post, 2006; Sen, 1999), as, "people are embracing democracy not only as a system of government, but also as a value" (McFaul, 2004, p. 152). Democracy thereby incorporates a value system that informs many people's evaluations about "good" and "bad" behaviour by citizens as well as about "good" and "bad" governance by governments.

In the present article, we adopt a social representations perspective (Moscovici, 1988; Sammut, Andreouli, Gaskell, \& Valsiner, 2015) by examining how shared representations of democracy inform lay thinking about the world and its inhabitants. Based on the conviction that contemporary social psychology should examine 
socio-cognitive processes at work in judgements of global categories, we show how idealised representations of democracy at the lay level are translated into antagonistic stereotypes of global categories, juxtaposing the simplified images of democratic populations to stereotypes of nondemocratic populations. While acknowledging the potentially inclusionary and empowering functions of democracy in other contexts, the present approach focuses on the "dark side" of democracy and on its exclusionary and justificatory functions (see Rosenmann, 2015).

The "democracy-as-value" research programme has demonstrated that democracy is an ideological belief system that provides intrinsic value to democratic individuals, groups, and institutions, therefore granting legitimacy to their actions, whatever the nature and moral justification of that action may actually be (Falomir-Pichastor, Staerklé, Pereira, \& Butera, 2012). In particular, we contend that in Western countries such as Switzerland (where most of the studies were carried out) representations of democracy can be invoked to legitimise hostile acts against nondemocratic groups. We also suggest that the influence of democracy-as-value on judgements of social categories is not limited to political judgements of countries, but that it also infuses judgements of groups in mundane settings through establishing a moral hierarchy between groups based on their internal organisation.

\section{GLOBAL VALUE PERCEPTIONS}

Following Middle Age explorations that revealed the existence of hitherto unknown human populations, Europeans have come to consider themselves as economically, politically, and morally superior compared to non-Europeans. Arguably, the antagonism between democracy and nondemocracy represents the political facet of a range of antagonistic stereotypes at the global level, including the opposition between the East and the West (Said, 1978), between civilisation and savagery (Jahoda, 1999), or between the Christian and Muslim world (Yilmaz \& Ayka, 2011). These stereotype pairs can be seen as partially overlapping instances of global value perceptions developed and disseminated by Western powers. They associate respectively positive and negative value to social categories spread out over the entire world.

However, a crucial difference sets the global juxtaposition of democratic and nondemocratic contexts apart from other intergroup hierarchies. When judging organised groups such as countries (as opposed to social categories in general), people do not only have a stereotype of a specific group in mind, but also think of the organisational structure of these groups. Applied to judgements of countries, people think of different ways of politically organising a society as a function of the roles attributed to national populations and governments. That is, they think of issues of social order and political legitimacy. We further suggest that this perceived polarity between a democratic and a nondemocratic ideal-type of social order has become a powerful organising principle of international representations. As such, democracy represents the normative ideal of a social order in which a population of allegedly rational and equal citizens spontaneously organises into an orderly society that collectively decides by whom it wishes to be governed. The basic primacy of the individual over the group in the West is a key characteristic of liberal political philosophy that has led to this widespread common sense assumption that liberal democracy constitutes the normal, "good" social order (see Moscovici, 1986; Nisbett \& Ross, 1980).

\section{LAY THEORIES OF DEMOCRATIC AND NONDEMOCRATIC POPULATIONS AND GOVERNMENTS}

In order to compare representations of a democratic and a nondemocratic social order, a first series of experimental studies investigated the perceived relationship between democratic and nondemocratic populations and governments (Staerklé, Clémence, \& Doise, 1998). Participants were asked to estimate human rights respect in a fictitious nation characterised only as having a democratic or a nondemocratic government and a negotiating (i.e. orderly) or clashing (i.e. unruly) citizenry. The respective stereotypes of orderly vs. unruly were contextualised in the instruction "Think of a country in which the inhabitants are quite orderly [unruly] and resolve their conflicts often by discussion [clashes]." We chose these attributes to highlight a stereotypically democratic order in which competing interests and conflicts are negotiated through (rational) discussion and debate, in opposition to a stereotypically nondemocratic order in which different segments of the population clash with each other over their disagreements.

The findings of a first study showed that judgements of countries with democratic governments were similar to judgements of countries with orderly populations, but different from the other pair of countries defined by nondemocratic governments or unruly populations. In another study, population and government types were crossed. This study showed that human rights were perceived to be well respected only in countries with democratic governments inhabited by orderly (i.e. democratic) inhabitants, and much less so in democratic countries with unruly (i.e. nondemocratic) inhabitants.

These results suggest that for these participants, a democratic country is truly democratic only when its population matches the stereotype of an orderly democratic population. For nondemocratic governments, the type of population did not affect judgements, indicating a greater role attributed to nondemocratic compared with democratic governments. Other findings of these studies confirmed this pattern: human rights respect was associated with the population resisting a rights-violating government in democratic, but not in nondemocratic contexts, suggesting that political citizen activism in nondemocratic contexts was perceived as inconsequential. 
Overall, these studies suggest that these Swiss samples had clear expectations as to the type of population who inhabit democratic or nondemocratic countries, an expectation possibly based on opposing lay theories of democratic and nondemocratic social order. They also suggest that respondents explicitly valued a democratic societal organisation in which respect of human rights at least partially resulted from a politically active democratic population rather than from a fair government.

Another study assessed stereotype content spontaneously associated with democratic and nondemocratic populations, using the same vignettes as above (Staerklé, 2005). In these open-ended questions, free, independent, democratic, open-minded, egalitarian, and responsible were the most frequently quoted attributes of democratic inhabitants, whereas submissive, unhappy, powerless, not free, poor, dependent, and easy to manipulate were the typical attributes of nondemocratic populations. These findings suggest that stereotypes of nondemocratic populations are construed as a violation of the democratic values of individual freedom and independence (see Biernat $\delta$ Vescio, 2005; Joffe \& Staerklé, 2007).

Taken together, these studies provide converging, albeit indirect, evidence of the existence of lay theories about democratic and nondemocratic forms of social order. Defining a democratic social order in contrast to a nondemocratic social order is a strategy to highlight the positive attributes of democratic populations (e.g., self-determination, civility, freedom, and equality) and the negative attributes of nondemocratic populations (e.g., submissiveness, obedience, poverty, and unruliness). Such dual representations anchored in common sense knowledge about "democracy" may give individuals the impression of familiarity and understanding of remote and unknown countries that are simply represented as "nondemocratic" (see Herrmann, Voss, Schooler, \& Ciarrochi, 1997, for a similar argument concerning stereotypic images of countries). Said (1978) made a related point when he observed that, for the West, the Orient was a "mute" outgroup without the right to voice, thus employed by the West to project characteristics useful to sustain the self and public image of a free, equal, and civilised West.

\section{THE IDEOLOGICAL PREFERENCE FOR EQUALITY OVER HIERARCHY}

The findings of these studies suggest that the political organisation of a society determined the perceived characteristics of its citizens. The more democratic a country, the more its inhabitants were evaluated as possessing positive and desirable attributes. Still, these studies did not clarify how this core value of democracy and its nondemocratic counterpart affected social judgements. We reasoned that this issue could only be understood by examining judgements other than those directly related to actual country judgements and international relations. We therefore developed another experimental paradigm that would not be based on judgements of actual countries, but would rely on a more formal manipulation of key characteristics of democratic and nondemocratic forms of group organisation. In order to develop such a paradigm, an operational key feature of democracy was required.

Most normative accounts of democracy converge in the idea that formal or procedural equality between group members is a necessary characteristic of democratic governance (see Habermas, 1994). In deliberative theories, for example, democracy requires members to hold equal power and equal opportunity to access political influence. That is, in order to reach a legitimate democratic decision, group members should all have an equal chance to voice their distinctive views, with group leaders having only a subsidiary role (Myers \& Mendelberg, 2013). More generally, procedural equality can be defined as the equal weight of judgements of all members of a community on a given matter, resulting in majority rule (see for example Dahl, 1989). This classical view of democratic decision-making is consistent with liberal political philosophy that considers the individual as the ultimate bearer of rights. Democratic citizens are therefore seen as equal and sovereign individuals, capable of taking informed decisions without being subjected to political or other authorities. This normative view of democratic governance is (implicitly) contrasted with nondemocratic forms of governance defined by large power differentials between group members and leaders and by unilateral decision-making by nondemocratic leaders. An authoritarian government follows the principles of a hierarchical social order by controlling a citizenry construed as passive and submissive. ${ }^{1}$

Research on procedural justice, in turn, suggests that people generally prefer an egalitarian order to a hierarchical order. At least in Western countries, the formal right and actual opportunity to voice one's concerns and to actively participate in the decision-making process are key determinants of perceived procedural justice (e.g., Lind \& Tyler, 1988; Thibaut \& Walker, 1975; Tyler $\delta$ Lind, 1992). In idealised views of democracy where all citizens have their say, individual citizens feel as valued and respected group members (Tyler, 2011). A recent survey study confirmed that direct popular voice exerted on political authorities is particularly attractive in Western European countries: Adolescent respondents across 18 European countries perceived direct democracy as the fairest decision-making procedure, followed by group representation, representative democracy, and oligarchy (Ellenbroek, Verkuyten, Thijs, \& Poppe, 2014).

Based on these political and psychological benefits of procedural equality, in Western contexts the

\footnotetext{
${ }^{1}$ Our focus on procedural equality in lay definitions of democracy does not imply that other characteristics (e.g., the respect of minority, social, and civil rights) would be less important in actual definitions of democracy (see Shapiro, 2003). Likewise, it does not imply that Western countries are only or predominantly egalitarian, since countries mix egalitarian and hierarchical characteristics (see Triandis \& Gelfand, 1998).
} 
valence granted to democratic-egalitarian groups should be more positive than the valence granted to nondemocratic-hierarchical groups. Studies in France and Switzerland have shown that the psychological attributes necessary for an egalitarian order such as independence, autonomy, and rationality were more valued than hierarchy-reflecting attributes such as obedience, conformity, and compliance (Beauvois, 2005; LorenziCioldi, 1998). This liberal view of the individual is arguably part of a hegemonic social representation that informs common sense conceptions of democracy (Moscovici, 1986; Sampson, 1988). As a result, at least in Western societies, egalitarian-democratic groups should be more desirable and more valued than hierarchical-nondemocratic groups, everything else being equal. This is the basic assumption of the democracyas-value hypothesis.

This general ideological preference for an egalitarian order is however far from absolute. There is abundant research suggesting that under many circumstances people actually prefer hierarchical forms of social order: hierarchical groups meet motivations for social conformity by authoritarian individuals (Feldman, 2003), satisfy core needs of order and control (Friesen, Kay, Eibach, $\delta$ Galinsky, 2014) and are seen as more effective to achieve group goals (Halevy, Chou, \& Galinsky, 2011). Nevertheless, this preference for hierarchical groups seems tied to specific circumstances and targeted goals, whereas the preference for egalitarian groups is likely to be driven by broader ideological motives and therefore more widespread and deep-seated in Western countries.

The assumption underlying our studies is that this fundamental preference for (procedurally) egalitariandemocratic over hierarchical-nondemocratic systems affects not only perceptions of members of these two systems, but, crucially, also the perceived legitimacy of their actions. The early studies did not involve an intergroup design and thus did not examine the contention that democracy value would provide justification for the self-ascribed political and moral superiority of democratic countries. Indeed, if democracy is a value represented by dominant groups, it should play a justificatory role for democratic superiority and by implication, for actions perpetrated by democratic groups. This is similar to the way other dominant values (e.g., meritocracy or the protestant work ethic) justify the superior social position of dominant groups who define themselves through these values (Biernat $\&$ Vescio, 2005; Deschamps, 1982; Sidanius \& Pratto, 1999).

\section{THE LEGITIMACY OF DEMOCRATIC ACTIONS}

In order to test the above deduction, we investigated how the key feature of democratic and nondemocratic social order-equality and hierarchy between group members-affects judgements of intergroup aggression. Specifically, we tested judgements of hostile and aggressive actions perpetrated either by egalitarian-democratic or by hierarchical-nondemocratic groups, at the expense of a victim group also defined as either egalitarian or hierarchical (Falomir-Pichastor, Staerklé, Depuiset, \& Butera, 2005, 2007).

The studies were explicitly created to mimic realworld conflict between democratic (Western) and nondemocratic (non-Western) countries. In light of this global context, we wanted to test the hypothesis that actions taken by democratic actors, even if aggressive, immoral, or harmful for other groups, were considered more legitimate than identical actions initiated by nondemocratic groups. The experimental paradigm featured a scenario in which two summer camp groups, organised either in an egalitarian or hierarchical way, were in conflict with each other. At some point, members of one group physically attacked members of the other group. Findings revealed that the aggression perpetrated by democratic group members against nondemocratic victim group members was perceived as more legitimate than any other perpetrator-victim group combination, thereby providing direct support for the democracy-as-value hypothesis (Falomir-Pichastor et al., 2005). Notably, degree of severity of the aggressive action did not interact with group organisation, suggesting that the democracyas-value hypothesis was stable across levels of aggression severity.

Another set of studies tested hypotheses derived from the democracy-as-value framework directly in a geopolitical context. Participants evaluated the legitimacy of military action initiated by democratic or nondemocratic countries (Falomir-Pichastor, Staerklé et al., 2012). In order to avoid instrumental or identity-related judgements of countries, these studies adopted a third-party perspective in which military interventions between two allegedly existent, but in fact fictitious, countries were evaluated. In addition, given the globalised scale of opinion communication, these studies introduced national public opinion as another key factor shaping perceived legitimacy of democratic and nondemocratic actions. In line with procedural justice theories (Tyler \& Lind, 1992), people should expect only egalitarian-democratic governments to make decisions based on public opinion. Moreover, the legitimacy of democratic governments is largely based on the support or at least tacit public consent for their policies (Glasser \& Salmon, 1995). Hence, we reasoned that perceived popular support should enhance the legitimacy of military interventions of democratic countries, in particular when they target nondemocratic countries. This should be less the case in nondemocratic contexts for which respondents should consider public opinion irrelevant, given the assumed power differential between nondemocratic governments and populations.

In order to test these hypotheses, participants read about a conflict between two fictitious countries. The political organisation of perpetrator and victim countries was experimentally manipulated in both studies, while public support for military action was either measured or manipulated. In line with our expectations, both studies confirmed that direct military action by a democratic government was perceived as being the least illegitimate when the democratic population 
supported their government's policy to attack a nondemocratic country. By demonstrating the legitimising role of democratic public opinion in backing its government's hostile actions against a nondemocratic enemy, the studies provided further support for the democracy-as-value hypothesis.

The question of perceived legitimacy of military actions is not only relevant for conflicts between two rival countries. In international relations, military interventions are often carried out in the name of a superordinate category such as the United Nations or NATO. Given that dominant voices in these superordinate categories are represented by countries that pride themselves on being democratic, it could be expected that international military interventions should be deemed more legitimate when targeted against nondemocratic rather than (fellow) democratic countries. This was the setup for two studies that examined the support for international military interventions as a function of the political organisation as well as public opinion of the target country (Falomir-Pichastor, Pereira, Staerklé, \& Butera, 2012). In this scenario, participants were told that the international community (i.e. the U.N.) considered a possible military intervention against a sovereign country whose government threatened to use military power against a secessionist region. In order to emphasise the hostile character of this intervention, it was made clear that it would likely cause a massive number of civilian casualties. In addition, depending on the study, public support for the aggression against the secessionist region was either measured or experimentally manipulated. The findings confirmed the prediction that international military action is more easily legitimised when it targets aggressive nondemocratic rather than democratic countries, but only when its nondemocratic population supported the aggressive government policy. For democratic target countries, support for the U.N. intervention was low, irrespective of democratic public opinion. These studies thereby suggest that civilian casualties were more acceptable in nondemocratic rather than democratic contexts, indicating that democratic lives might have been perceived as more valuable than nondemocratic lives. In addition, the prominent role of nondemocratic public opinion (compared to the studies described above where democratic public opinion justified its government's aggressive actions) suggests that nondemocratic public opinion may be used to justify an aggressive act against them (when they agree with their government) rather than to justify actions by them (because public opinion is irrelevant for nondemocratic governments).

\section{DEMOCRATIC VALUE PROTECTION AND COLLECTIVE PUNISHMENT}

The studies discussed so far have provided convergent evidence for the democracy-as-value hypothesis, demonstrating that democratic actions, in particular when they inflict harm on nondemocratic rival groups, were perceived as more legitimate than the same actions perpetrated by nondemocratic groups, or those perpetrated at the expense of other democratic groups. In order to enhance the validity of this general hypothesis, we used another strategy to assess the democracyas-value phenomenon, namely collective punishment for offences committed by democratic or nondemocratic group members. In line with the early sociological insight that norm transgressions are a threat to social order (Durkheim, 1893), punishment of offenders is seen as a strategy to restore social order and to reaffirm and symbolically protect core values of society (see also Tyler \& Boeckmann, 1997; Vidmar \& Miller, 1980).

An early study using the summer camp paradigm (Falomir-Pichastor et al., 2007) analysed the perceived legitimacy of collective punishment of democratic and nondemocratic groups for an offence committed by their individual group members. The findings of this study paralleled the pattern found with the perceived legitimacy of aggression (FalomirPichastor et al., 2005): collective punishment was the least legitimate when democratic group members attacked nondemocratic group members, compared to the three other conditions. Put otherwise, participants protected the democratic group from harsh punishment and thereby symbolically reaffirmed the value of democracy. In addition, the results also revealed that democratic group members who had attacked nondemocratic members were credited with higher moral value (in terms of personal attributes such as being moral, fair, and respectful) than the other three groups, and that this higher moral value mediated the effect of group organisation on collective punishment. This finding suggests that a legitimising process was at work in evaluations of aggression committed by a democratic group against a nondemocratic group, since it is in this condition that democratic group members were seen as morally superior, "better" persons.

Having established that democratic groups that have committed wrongdoings against nondemocratic groups are likely to be treated relatively leniently and that their misdeeds are more easily condoned, a closer examination of the psychological processes involved in this basic phenomenon is called for. In particular, we wanted to identify individual-level moderators in order to examine for whom the phenomenon is more or less likely to occur. In a series of studies (Pereira, Falomir-Pichastor, Berent, Staerklé, \& Butera, 2015), we examined how individual preference for a democratic or nondemocratic group organisation affected judgements. The straightforward prediction was that individuals who strongly endorsed the value of democracy should exhibit a greater tendency to base their judgements on the value of democracy, compared to those with a weaker endorsement of democratic group organisation.

In order to measure the extent to which participants personally value a democratic group organisation, participants first read the descriptions of the two types of groups and then indicated which one of the two types of groups was fairer, more efficient, had happier 
members, and which they personally preferred. The findings of a first study using the aforementioned summer camp paradigm showed that respondents with a stronger preference for democratic group organisation punished most severely the nondemocratic offender group for having attacked a democratic group, confirming expectations. In order to enhance the ecological validity to these findings, a second study introduced a new paradigm that involved plagiarism among university students. Participants were told that in order to finalise an assignment, democratically or nondemocratically organised work groups stole information from another workgroup. Again, the findings revealed that respondents high in preference for democratic group organisation protected the democratic student group that had stolen information from a nondemocratic group from collective punishment.

The consistency of these findings makes it clear that democracy as a value is an important organising principle of a wide range of intergroup judgements. The tendency to shield a democratic group from the consequences of its misdeeds seems to be widespread, and even enhanced among those who explicitly value a democratic group organisation. Democracy thereby plays a justificatory role in everyday intergroup situations, including student work contexts and adolescent summer camps.

\section{DEMOCRATIC ACCOUNTABILITY}

There is a paradox in these findings: How is it possible that democratic groups who are expected to collectively take responsible and informed decisions are suddenly exempted from any moral wrongdoing? Could it nevertheless be that, under certain circumstances, democratic groups would be more severely punished than nondemocratic groups? Democratic accountability should in fact lead people to consider that democratic group members are collectively responsible for their decisions, and thus more severely punished for group misdeeds. In other words, the purported higher moral standards of democratic groups should lead people to hold higher expectations and standards of judgement for democratic compared to nondemocratic groups.

There is indeed considerable evidence showing that socially valued groups and individuals such as ingroups and group leaders do not necessarily receive a more lenient treatment following their misdeeds. Expectancy violation theory (Jussim, Coleman, \& Lerch, 1987), for example, suggests that people hold high expectations regarding the behaviour of socially valued groups. As a result, deviations from the expected behaviour are considered more serious and lead to a stronger willingness to sanction these groups (Biernat, Vescio, \& Billings, 1999; Jussim et al., 1987). The subjective group dynamics model (Marques, Abrams, \& Serodio, 2001), in turn, specifies the conditions under which valued groups (ingroups in particular) are more severely punished than non-valued (out-)groups, thereby reversing the usual pattern of ingroup favouritism in retributive judgements. The theory stipulates that if a misdeed by an ingroup member severely tarnishes the positive self-image of a group, group members may be motivated to restore this positive image by symbolically excluding the offending ingroup member. Recent research in retributive justice has demonstrated that offender responsibility is a key moderator of this mechanism. Harsher judgements were observed in cases where the responsibility of an offender was clear-cut and unambiguous and where the offense could not be excused or minimised. More lenient judgements, in turn, resulted from ambiguous situations where offender responsibility was unclear and vague (Van Prooijen, 2006, 2010).

Based on these considerations, it should be possible to reverse the greatest relative clemency afforded to democratic group's aggression against a nondemocratic victim. A series of studies examined the impact of collective responsibility (manipulated as the extent to which other group members could be held accountable for an individual wrongdoing) on retributive judgements of democratic and nondemocratic offender groups. Using various versions of the student plagiarism paradigm, the summer camp paradigm as well as a new paradigm on fan violence during an ice hockey game, the findings consistently demonstrated that collective responsibility increased support for collective punishment (Pereira, Berent, Falomir-Pichastor, Staerklé, \& Butera, 2015). Importantly, five studies showed the expected moderation of this effect by the offender group's social organisation: For democratic groups, support for collective punishment increased in parallel to their collective responsibility. For nondemocratic groups, however, there was in most cases no relationship between collective responsibility and collective punishment. Additional analyses suggest that expectancy violations and damage to group value were behind this effect.

\section{DISCUSSION AND CONCLUSION}

In the first part of this article, we examined how the antagonism between democracy and nondemocracy gives rise to stereotypes of democratic and nondemocratic populations. In line with an idealised conception of democracy, Western populations were seen as free and strong, capable of choosing their government and thus determining the fate of their country. NonWestern populations, in turn, were viewed as weak, manipulated, and compliant to a crushing government (Staerklé, 2005; Staerklé et al., 1998). We then proposed procedural equality as the defining feature of a democratic social order, and reported research demonstrating that aggressions perpetrated by democratic groups against nondemocratic groups were perceived as more legitimate than any other perpetrator-victim group combination. These findings support the idea that the value of democracy has an instrumental function in regulating relations between groups (Falomir-Pichastor et al., 2005, 2007). Other findings showed greater support for the intervention of the international community (such as the U.N.) against nondemocratic targets. Interestingly, this was the case in 
particular when a nondemocratic population supported the belligerent policy of its own government (Falomir-Pichastor, Pereira, et al., 2012). Moreover, direct military action by a democratic government was perceived as being least illegitimate when the population supported their democratic government's policy to attack a nondemocratic country (Falomir-Pichastor, Staerklé, et al., 2012). Finally, the most recent studies investigated processes underlying retributive justice judgements as a function of collective responsibility and moral accountability of democratic and nondemocratic groups (Pereira, Berent et al., 2015) and as a function of individual endorsement of the value of democracy (Pereira, Falomir-Pichastor et al., 2015).

In sum, it appears that the value of democracy is based on the alleged moral and political superiority of an idealised democratic organisation of national and other groups. As such, it is a theory about hierarchies between groups and even nations, much like racism, sexism, or nationalism. The correct term would then be "democratism", denoting the intrinsic superiority of democracy over other types of group organisation. The findings of our research programme suggest that in a Western country such as Switzerland democratism is used as a standard of judgement of situations involving conflict between groups that can be differentiated by their internal organisation. While its main interest lies in the analysis of judgements of international relations, democratism also applies to a range of everyday situations that are disconnected from the political realm.

Democratism provides moral justification for harmful and hostile actions directed towards groups for the mere reason that they are construed as nondemocratic. Democratism is mainly at work in the context of rival intergroup relations in which the opposing group is perceived or strategically construed as lacking the essential quality of procedural equality of group members. This equality, however, is largely the product of a normative or idealised view according to which democratic group members are by definition independent, autonomous, rational individuals, capable of self-organising as a social group without the need for powerful leaders and governments telling them what to do. This idealised view of democratic equality reflects a liberal political philosophy that has been disseminated in Western societies for over two centuries (see Beauvois, 2005). Paradoxically, and in line with Orwell's opening quote, our findings demonstrate that the very values of rational deliberation and peaceful consensus-seeking on which a democratic group organisation is founded can be strategically used to justify nondemocratic forms of social regulation based on physical force and insufficient diplomatic efforts. ${ }^{2}$

\footnotetext{
${ }^{2}$ Even though minority (e.g., civil rights) groups may also appeal to democracy to justify their actions, they do so from a minority perspective, that is, their appeal to democracy is more likely a minority strategy designed to justify actions in favour of social change, rather than a majority strategy aimed at legitimising hegemony and negative outgroup treatment (Staerklé, 2015).
}

A number of issues concerning these studies and their interpretation should be addressed. First, one might argue that our findings merely reflect a common ingroup bias in the sense that participants self-categorise as members of democratic groups and, in line with social identity and self-categorisation theory (Tajfel \& Turner, 1986), differentiate themselves positively from nondemocratic outgroups with judgements favouring democratic groups. This might indeed have been the case in the studies where the democratic group is explicitly an ingroup, in particular in the Staerklé et al. (1998) studies where some participants indicated their national ingroup (Switzerland) when prompted to think of a democratic country. Yet, precisely in order to rule out an ingroup bias explanation of our findings, in all subsequent studies we chose fictitious (national, adolescent, student, or sport supporter) groups with which identification was implausible. In addition, in the Falomir-Pichastor et al. (2005) study we did measure identification with the summer camp groups and found no mediating effect on the outcome variables. In sum, identification with particular groups and defence of ingroup interests are not plausible accounts for the observed legitimising effects.

This does not mean, however, that categorisation processes are irrelevant to the democracy-as-value approach. Democratic groups may for example engage in superordinate categorisation to the extent that they consider themselves as the legitimate representatives of a superordinate category (for example, when the U.S. sees itself as the "world police"). In line with the ingroup projection model (Wenzel, Mummendey, \& Waldzus, 2007), democratic ingroups would project their values onto superordinate categories. This would result in perceived prototypicality of their (democratic) ingroup and in (nondemocratic) outgroup difference construed as deviance, and hence legitimately punishable. Recent research corroborates such a view, showing that respondents from developed countries perceived their group as more prototypical of the world population than citizens from developing countries. These perceptions of ingroup prototypicality in turn were related to negative behavioural intentions towards developing countries and thus to the perpetuation of global inequalities (Reese, Berthold, \& Steffens, 2012). This interpretation in terms of superordinate projection of democratic values does not question the validity of our findings. Democracy may be a special case of a broader tendency to use cultural values to legitimise intergroup outcomes (a "legitimising myth", Sidanius \& Pratto, 1999), but one that is specifically called upon when hostile or immoral acts of a (dominant) ingroup and negative treatments of (subordinate) outgroups need to be justified.

Still other explanations of our effects are possible. Individuals may for example consider democratically reached decisions to be of a higher quality than hierarchically reached decisions. According to a logic of informational conformity, people living in democracies (such as our respondents) may be motivated to validate their own opinions by endorsing a democratically reached 
majority decision and by extension by supporting democracies against nondemocracies. Nevertheless such an explanation in terms of informational conformity does not seem plausible either, because in most of our studies participants were not evaluating group-based decisions as such, but were rather judging national populations and governments and evaluating the legitimacy of acts committed by individual group members.

We should also discuss the implications of our experimental paradigm that juxtaposes a priori defined democratic-egalitarian and nondemocratic-hierarchical groups. This dichotomous categorisation may seem an oversimplified, black-and-white approach that runs the risk of essentialising social groups that usually combine egalitarian and hierarchical elements. This choice was nevertheless necessary, because we wanted to compare judgements on normative ideal-types of democratic and nondemocratic groups. By no means do we claim that our operating definitions represent accurate proxies of real-world groups; rather they are core elements of shared representations referred to by individuals in their everyday thinking.

Regarding the generalisability of the abovementioned phenomena, we should first mention that the 20 published studies reported in this review were carried out over almost two decades and used various participant samples, including young high school students, university students of various disciplines, members of youth associations (Scouts), and military personnel. This relative diversity ensures that our conclusions are not solely based on university students. Nonetheless, the relative homogeneity of our participants and the fact that our studies were mostly carried out in one specific country (Switzerland, two studies were carried out in France) does raise the question of the generalisability of our findings to more general processes occurring in the Western world. It is worth reiterating that our research is specifically concerned with Western representations, and we certainly do not claim any universality to the democracy-as-value hypothesis. A historically contingent understanding of the differentiation between "Europeans" and "Non-Europeans" suggests that our findings can most plausibly be generalised to other Western European countries, and possibly also to other English-speaking Western countries such as the U.S.

The question whether the observed findings could be replicated in non-Western countries cannot easily be answered, as there are good reasons why they should (because some might endorse Western ideas of liberal democracy), but also good reasons why they should not (because some might define themselves against Western ideas of liberal democracy). It is an empirical issue worth studying in itself. We do however believe that the convergent findings from our research programme allow a generalisation that goes beyond the Swiss context where most studies were carried out, even though we cannot exclude the possibility that the specificities of the Swiss political system (direct democracy, numerous popular votes) affected our findings.
Another issue concerns the psychological motivations underlying our results. We made it clear that we view our findings as essentially driven by political and ideological motives, that is, people prefer and defend egalitarian-democratic groups because they see democracy in itself as a value and treat it as a normative ideal groups and societies should strive for. On an individual level, we argued that this preference for egalitarianism is rooted in procedural justice, because egalitarian groups offer important psychological benefits (voice, respect, identity, etc.) compared to hierarchical groups. On a collective level, we can only speculate about the origins of this kind of thinking. Nevertheless, we see it as an expression of widely disseminated common sense knowledge-social representations (Moscovici, 1988) — that guides and orients judgements of intergroup legitimacy. These representations are acquired through various channels of everyday communication, including media exposure, education, formal and informal discussion with friends, parents, teachers, and so on (see Glasser \& Salmon, 1995). Representations of democracy need not be consensual; some individuals may be better informed and more knowledgeable about world affairs, whereas others may have a critical and negative attitude towards democratic and Western countries. Nevertheless, social representations of democracy still constitute common sense, taken-for-granted reference knowledge drawn upon by citizens to discuss difficult and complicated issues. It is even likely that representations of democracy can be seen as what Moscovici (1988) called "hegemonic representations", that is, pervasive large-scale social order narratives and systems of classification that define historical eras and societies (see Staerklé, 2015).

This representational approach is not necessarily incompatible with other accounts of legitimising processes, for example motivated cognition theories that focus on the psychological benefits of legitimacy (e.g., Jost et al., 2010). Our account differs from motivational theories inasmuch as democracy judgements in our paradigm do not primarily serve psychological needs, but rather reflect the influence of shared, ideological knowledge on intergroup judgements. People are primarily "motivated" to defend democracy not because it makes them feel good about themselves, but because they have learned that democracy is "good".

From a more historical perspective, the legitimising representations of democracy uncovered in our studies can be viewed as the reflection of longstanding persuasive and strategic communication strategies advanced by Western elites in order to justify Western hegemony (Said, 1978). Pitting the West against the rest of the world has become a mainstay of Western political thinking. Many Western leaders seem to use these simplified and distorted global dichotomies to justify aggressive foreign policy decisions, while milder manifestations of the antagonism are also found in both scientific and common sense discourse. In 1992, Francis Fukuyama published his influential book on the "End of history", 
claiming that liberal democracy constitutes the final and most accomplished form of human government. At the same time, Samuel Huntington (1993) developed a related "West against the rest" argument, suggesting that the major source of conflict in the future will be based on cultural differences between global geopolitical regions. Both of these widely known texts are based on arguments of liberal hegemony associated with the Western world. By and large, we could say that the participants' responses in our studies reflect Fukuyama's and Huntington's logic inasmuch as they reveal this alleged intrinsic superiority of Western countries. Interestingly, such conceptions of inter-societal hierarchy in lay thinking were also found in a study on folk beliefs about globalisation in China, Japan, and Australia (Kashima et al., $2011)$. It shows that lay perceivers believe that societies develop from a traditional community where people are trustworthy though unsophisticated to a more sophisticated, but less warm-hearted modern society. The global value-perceptions approach that we have developed in the present article, in turn, unveils the pervasive psychological power of representations of global categories in justifying power arrangements in favour of the Western world.

This raises the question of our own positioning towards the issues we study. In stark contrast to Fukuyama and Huntington, we doubt the thesis of liberal hegemony (see Derrida, 1994). In line with George Orwell's opening quote, our studies challenge the strategic and political (mis-)use of consensually positive cultural values by unmasking their hidden meanings, which are actually at odds with their original meaning. This goal is not specific to our research, but reflects the very reason of existence of many other disciplines in the social sciences. By demonstrating how lay people in a Western country associate the idea of democracy to "good" people and to "good" actions (see Crandall \& Beasley, 2001, for a related argument), we question the convenient and taken-for-granted truth of the moral good of democracy. Following the colloquialism that "fish do not notice the water they are swimming in", for people living in Western democracies the moral good of democracy may be like a fish's water. Our goal is to better understand the ideological water Western populations swim in. ${ }^{3}$

\section{REFERENCES}

Beauvois, J. L. (2005). Les illusions libérales, individualisme et pouvoir social: Petit traité sur des grandes illusions [Liberal illusions, individualism and social power: Little treatise on big illusions]. Grenoble: Presses Universitaires de Grenoble.

Biernat, M., \& Vescio, T. K. (2005). Values and prejudice: Historical conceptualizations and current issues. In C. S. Crandall \& M. Schaller (Eds.), The social psychology of prejudice: Historical and modern perspectives (pp. 187-211). Lawrence, KS: Lewinian Press.

\footnotetext{
${ }^{3}$ We thank an anonymous reviewer for this metaphor.
}

Biernat, M., Vescio, T. K., \& Billings, L. S. (1999). Black sheep and expectancy violation: Integrating two models of social judgment. European Journal of Social Psychology, 29, 523-542. http://dx.doi.org/10.1002/(SICI) 1099-0992 (199906)29:4<523::AID-EJSP944>3.0.CO;2-J

Brettschneider, C. (2006). The value theory of democracy. Politics, Philosophy $\theta$ Economics, 5, 259-278. http://dx.doi. org/10.1177/1470594X06068300

Crandall, C. S., \& Beasley, R. K. (2001). A perceptual theory of legitimacy: Politics, prejudice, social institutions, and moral value. In J. T. Jost \& B. Major (Eds.), The psychology of legitimacy: Emerging perspectives on ideology, justice, and intergroup relations (pp. 77-102). New York: Cambridge University.

Dahl, R. (1989). Democracy and its critics. New Haven, CT: Yale University Press.

Derrida, J. (1994). Specters of Marx. The state of the debt, the work of mourning $\theta$ the new international. New York: Routledge.

Deschamps, J.-C. (1982). Social identity and relations of power between groups. In H. Tajfel (Ed.), Social identity and intergroup relations (pp. 85-98). Cambridge: Cambridge University Press.

Durkheim, E. (1893). De la division du travail social [About division of social work]. Paris: Presses Universitaires de France.

Ellenbroek, M., Verkuyten, M., Thijs, J., \& Poppe, E. (2014). The fairness of national decision-making procedures: The views of adolescents in 18 European countries. Journal of Community and Applied Social Psychology, 24, 503-517.

Falomir-Pichastor, J. M., Pereira, A., Staerklé, C., \& Butera, F. (2012). Do all lives have the same value? Support for international military interventions as a function of political system and public opinion of target states. Group Processes $\theta$ Intergroup Relations, 15, 347-362. http://dx.doi. org/10.1177/1368430211424919

Falomir-Pichastor, J. M., Staerklé, C., Depuiset, M. A., \& Butera, F. (2005). Democracy justifies the means: Political group structure moderates the perceived legitimacy of intergroup aggression. Personality and Social Psychology Bulletin, 31, 1683-1695. http://dx.doi.org/ $10.1177 / 0146167205278260$

Falomir-Pichastor, J. M., Staerklé, C., Depuiset, M.-A., \& Butera, F. (2007). Perceived legitimacy of collective punishment as a function of democratic versus non-democratic group structure. Group Processes $\theta$ Intergroup Relations, 10, 565-579. http://dx.doi.org/10.1 177/1368430207081543

Falomir-Pichastor, J. M., Staerklé, C., Pereira, A., \& Butera, F. (2012). Democracy as justification for waging war: The role of public support. Social Psychological and Personality Science, 3 , 324-332. http://dx.doi.org/10.1177/1948550611420172

Feldman, S. (2003). Enforcing social conformity: A theory of authoritarianism. Political Psychology, 24, 41-74. http:// dx.doi.org/10.1111/0162-895X.00316

Friesen, J. P., Kay, A C., Eibach, R. P., \& Galinsky, A. D. (2014). Seeking structure in social organization: Compensatory control and the psychological advantage of hierarchy. Journal of Personality and Social Psychology, 106, 590-609.

Fukuyama, F. (1992). The end of history and the last man. New York: Free Press.

Glasser, T. L., \& Salmon, C. T. (Eds.) (1995). Public opinion and the communication of consent. New York: Guilford.

Habermas, J. (1994). Three normative models of democracy. Constellations, 1, 1-10. http://dx.doi/org/10.1111/j.14678675.1994.tb00001.x 
Halevy, N., Chou, E., Galinsky, A. D. (2011). A functional model of hierarchy: Why, how and when hierarchical differentiation enhances group performance. Organizational Psychology Review, 1, 32-52. http://dx.doi.org/10.1177/ 2041386610380991

Herrmann, R. K., Voss, J., Schooler, T., \& Ciarrochi, J. (1997). Images in international relations: An experimental test of cognitive schemata policy. Pittsburgh: University of Pittsburgh Press.

Huntington, S. P. (1993). The clash of civilizations? Foreign Affairs, 72, 22-49.

Jahoda, G. (1999). Images of savages: Ancient roots of modern prejudice in western culture. London: Routledge.

Joffe, H., \& Staerklé, C. (2007). The centrality of the selfcontrol ethos in Western aspersions regarding outgroups: A social representational approach to stereotype content. Culture of Psychology, 13, 395-418. http://dx.doi.org/10.1177/ $1354067 X 07082750$

Jost, J. T., Liviatan, I., van der Toorn, J., Ledgerwood, A., Mandisodza, A., \& Nosek, B. A. (2010). System justification: How do we know it's motivated? In R. Bobocel et al. (Eds.), The psychology of justice and legitimacy: The Ontario symposium (Vol. 11, pp.173-203). Hillsdale, NJ: Erlbaum.

Jussim, L., Coleman, L. M., \& Lerch, L. (1987). The nature of stereotypes: A comparison and integration of three theories. Journal of Personality and Social Psychology, 52, 536-546. http://dx.doi.org/10.1037/0022-3514.52.3.536

Kashima, Y., Shi, J., Tsuchiya, K., Kashima, E. S., Cheng, S. Y. Y., Chao, M. M., \& Shin, S. H. (2011). Globalization and folk theory of social change: How globalization relates to societal perceptions about the past and future. Journal of Social Issues, 67, 696-715.

Lind, E. A. \& Tyler, T. R. (1988). The social psychology of procedural justice. N.Y.: Plenum.

Lorenzi-Cioldi, F. (1998). Group status and perceptions of homogeneity. European Review of Social Psychology, 9, 31-75.

Marques, J. M., Abrams, D., \& Serodio, R. G. (2001). Being better by being right: Subjective group dynamics and derogation of in-group deviants when generic norms are undermined. Journal of Personality and Social Psychology, 81, 436-447. http://dx.doi.org/10.1037/00223514.81.3.436

McFaul, M. (2004). Democracy promotion as a world value. The Washington Quarterly, 28, 147-163. http://dx.doi.org/ $10.1162 / 0163660042518189$

Moscovici, S. (1986). L'ère des représentations sociales (The era of social representations). In W. Doise \& A. Palmonari (Eds.), L'étude des représentations sociales [The study of social representations] (pp. 34-80). Neuchâtel: Delachaux \& Niestlé.

Moscovici, S. (1988). Notes towards a description of social representations. European Journal of Social Psychology, 18, 211-250.

Myers, C. D., \& Mendelberg, T. (2013). Political deliberation. In L. Huddy, D. O. Sears, \& J. Levy (Eds.), The Oxford handbook of political psychology (pp. 699-734). Oxford, UK: Oxford University Press.

Nisbett, R., \& Ross, L. (1980). Human inference: Strategies and shortcomings of social judgement. Englewood Cliffs, NJ: Prentice-Hall.

Orwell, G. (1946). Politics and the English language. Horizon, 13(76), 252-265.

Pereira, A., Berent, J., Falomir-Pichastor, J. M., Staerklé, C., \& Butera, F. (2015). Collective punishment depends on collective responsibility and political organization of the target group. Journal of Experimental Social Psychology, 56, 4-17. http://dx.doi.org/10.1016/j.jesp.2014.09.001

Pereira, A., Falomir-Pichastor, J. M., Berent, J., Staerklé C., \& Butera, F. (2015). In the name of democracy: The value of democracy explains leniency towards wrongdoings as a function of group political organization. European Journal of Social Psychology, 45, 191-203. http://dx.doi.org/ 10.1002/ejsp.2081

Post, R. (2006). Democracy and equality. Annals of the American Academy of Political and Social Science, 603, 24-36. http://dx.doi. org/10.1177/0002716205282954

Reese, G., Berthold, A., \& Steffens, M. C. (2012). We are the world-and they are not: Prototypicality for the world community, legitimacy, and responses to global inequality. Political Psychology, 33, 683-700.

Rosenmann, A. (2015). Alignment with Globalized-Western culture: Between inclusionary values and an exclusionary social identity. European Journal of Social Psychology. Advance online publication. http://dx.doi.org/10.1002/ejsp.2130

Said, E. (1978). Orientalism. London, UK: Penguin.

Sammut, G., Andreouli, E., Gaskell, G., \& Valsiner, J. (2015) (Eds.). The Cambridge handbook of social representations. Cambridge: Cambridge University Press.

Sampson, E. E. (1988). The debate on individualism: Indigenous psychologies of the individual and their role in personal and societal functioning. American Psychologist, 43, 15-22. http://dx.doi.org/10.1037/0003-066X. 43.1 .15

Sen, A. (1999). Democracy as a universal value. Journal of Democracy, 10, 3-17. http://dx.doi.org/10.1353/jod.1999.0055

Shapiro, I. (2003). The state of democratic theory. Princeton, NJ: Princeton University Press. http://www.cairn.info/revuecritique-internationale-2007-1-page-163.htm

Sidanius, J., \& Pratto, F. (1999). Social dominance: An intergroup theory of social hierarchy and oppression. New York: Cambridge University.

Staerklé, C. (2005). L'idéal démocratique perverti: Antagonismes dans les représentations du non-occident [The perverted ideal of democracy: Antagonism in representations of the non-West]. In M. Sanchez-Mazas \& L. Licata (Eds.), L'autre: Regards psychosociaux [The other: psychosocial views] (pp. 117-148). Grenoble: Presses Universitaires de Grenoble.

Staerklé, C. (2015). Social order and political legitimacy. In G. Sammut, E. Andreouli, G. Gaskell, \& J. Valsiner (Eds.), The Cambridge handbook of social representations (pp. 280-294). Cambridge: Cambridge University Press.

Staerklé, C., Clémence, A., \& Doise, W. (1998). Representation of human rights across different national contexts: The role of democratic and non-democratic populations and governments. European Journal of Social Psychology, 28, 297-226. http://dx.doi.org/10.1002/(SICI) 1099-0992 (199803/04)28:2<207::AID-EJSP865>3.0.CO;2-5

Tajfel, H., \& Turner, J. C. (1986). The social identity theory of intergroup behavior. In S. Worchel, \& W. G. Austin (Eds.), Psychology of intergroup relations (pp. 7-24.) Chicago, IL: Nelson Hall.

Thibaut, J., \& Walker, L. (1975). Procedural justice. Hillsdale: Erlbaum.

Triandis, H. C., \& Gelfand, M. J. (1998). Converging measurement of horizontal and vertical individualism and collectivism. Journal of Personality and Social Psychology, 74, 118-128. http://dx.doi.org/10.1037/0022-3514.74.1.118 
Tyler, T. R. (2011). Why people cooperate. Princeton: Princeton University Press.

Tyler, T. R., \& Boeckmann, R. (1997). Three strikes and you are out, but why? The psychology of public support for punishing rule breakers. Law and Society Review, 31, 237-265.

Tyler, T. R., \& Lind, E. A. (1992). A relational model of authority in groups. Advances in Experimental Social Psychology, 25, 115-191.

Van Prooijen, J.-W. (2006). Retributive reactions to suspected offenders: The importance of social categorizations and guilt probability. Personality and Social Psychology Bulletin, 32, 715-726. http://dx.doi.org/10.1177/0146167205284964

Van Prooijen, J.-W. (2010). Offender's social categorization: Ingroup bias or black sheep effect? In M. E. Oswald,
S. Bieneck, \& J. Hupfeld-Heinemann (Eds.), Social psychology of punishment of crime (pp. 211-229). Chichester: Wiley-Blackwell.

Vidmar, N., \& Miller, D. T. (1980). Socialpsychological processes underlying attitudes toward legal punishment. Law O Society Review, 14, 565-602.

Wenzel, M., Mummendey, A., \& Waldzus, S. (2007). Superordinate identities and intergroup conflict: The ingroup projection model. European Review of Social Psychology, 18, 331-372.

Yilmaz, H., \& Ayka, C. E. (2011) (Eds.) Perceptions of Islam in Europe. Culture, identity and the Muslim "Other". New York: Palgrave Macmillan. 